\title{
One Summer in Gdańsk: Poland's leadership in transition from the socialist legal model
}

\author{
MURRAY RAFF
}

\section{One Summer in Gdańsk}

In 1989 I was undertaking research at the University of Bremen into what became my $\mathrm{PhD}$ topic. ${ }^{1} \mathrm{I}$ had involved myself in peace and environmental issues in Melbourne ${ }^{2}$ and took great interest in the events taking place in Eastern and Central Europe.

I was invited to join the peace mission 'Sailing for Peace', organised under the UN Peace Council, involving 37 yachts from all around the Baltic Sea, and even from Moscow, in a 'peace flotilla', which met at Copenhagen and sailed to Lübeck (Federal Republic of Germany), Rostock (German Democratic Republic), Kołobrzeg, Gdynia, Gdańsk (Poland) and Klaipeda (Lithuania, USSR).

In each port, crew members engaged in discussions with local and regional political bodies and community groups, held public seminars on peace and environmental issues and even performed street theatre. It was a lovely summer and a perfect time to visit the beautiful city of Gdańsk, where our fleet docked in the old Hanseatic harbour just by the main town square. The level of excitement in Gdańsk was amazing and large crowds, as well as the Polish media, were very interested in our visit.

It is difficult to believe this was 20 years ago. Reading issues of the German news magazine Der Spiegel from that time reminds one of the state of excitement that East-West issues had reached in May, June and July 1989, with crucial events balanced on the edge of contention across the globe from Nicaragua to China. My involvement in Sailing for Peace and interest in the events that

Published as Raff (2003).

2 Raff $(1985,1987,1989)$. 
unfolded continue to stimulate my academic interest in issues arising in states in transition - the basis of my present project on rebuilding the civil law in states in transition with Dr Anna Taitslin, ${ }^{3}$ in which we have enjoyed generous cooperation with the National Europe Centre at The Australian National University and its Director, Professor Simon Bronitt.

The Polish election of 4 June 1989 for the popular chamber, the Sejm, and the new Senate was a leading experiment in the democratisation of socialist governmental structures. Poland had for many years been a centre of energy in demands for greater democracy - probably unrivalled in the socialist world. The world had observed martial law and the growth of the Solidarity movement around the trade unions and particularly the workers at the Lenin Shipyard in Gdańsk. The juxtaposition of the maturity and relative peacefulness of the Polish election with the violent tragedy of the Tiananmen Square massacre ${ }^{4}$ - both on 4 June 1989 - highlights Polish leadership in dealing with democratisation and transition. In this chapter, I wish to trace Poland's leadership back to earlier points, particularly in the advancement of civil law and property rights under socialism.

\section{Poland's Leadership in Transition from the Socialist Legal Model}

This chapter is an early exploration of the transition of Poland's legal system within a wider project that examines the legal systems of a number of formerly socialist states in Europe and Asia with the objectives of examining: i) the status and operation of the civil law and the property model adopted in socialist states; ii) steps taken to rebuild civil law and settle post-socialist property issues; and forming a view on iii) desirable policy and strategy with respect to, and the priority of, rebuilding the capacity of civil law institutions and restructuring property holdings in states in transition. On the basis of research to date, a hypothesis is emerging that the strength of civil law institutions in transition is an important factor in the re-establishment of a liberal legal system, which contributes to success of the transition more broadly. The experience of Poland has contributed to the formation of this hypothesis.

The importance of the civil law in a Western legal system is widely underestimated. The civil law is the means by which citizens are able to challenge the legality of each others' actions horizontally within society, without recourse to top-down

3 Raff (2008) and Raff and Taitslin (2006-07).

4 In the issue of Der Spiegel (12 June 1989), report of the latter (pp. 142-54) greatly overshadows the former (p. 155). See also the pre-election interview with a philosophical Prime Minister, Mieczysław Rakowski (Der Spiegel, 29 May 1989:165-76), and post-election interview with Lech Wałęsa (Der Spiegel, 19 June 1989:124-5). 
regulatory agencies in the public law sphere, which might be unreliable, underresourced or pursuing other priorities. Even citizens who hold public offices are generally amenable to civil litigation. The risk of civil law liability is a significant disincentive to antisocial behaviour, ${ }^{5}$ and thus the civil law constitutes a very important pillar of the rule of law. Its effectiveness risks being undermined by inaccessibility, removal of its key institutions or compromise of the independence of the judiciary. Historically, the civil law has not fared well under socialism. Complete abolition of civil law was an ideal of the revolutionary Bolsheviks in 1917. It was at best incompletely regained in the Soviet era. ${ }^{6}$ The restoration of citizens' access to civil justice and its effectiveness are thus priorities in the transition from socialism, especially while the state remains unreliable, underresourced or pursuing other priorities.

That the apparent duality of de jure and de facto exercises of power is in reality a spectrum - and probably multidimensional at that - is a widely debated issue in postmodern legal thought. ${ }^{7}$ Although de facto exercise of political power through a one-party state has been the dominant factor in the lives of millions of people over decades, a lawyer will not neglect consideration of the de jure structures of the state in constitutions, assemblies, presidential powers and guarantees of freedom from persecution. This is not simply empty legal facadism. It is important in legal analysis that mob violence against Polish citizens in areas of Poland occupied by the Soviet Union in 1939-41 was a gross violation of Soviet law, ${ }^{8}$ for example. For the lawyer, one very important question arising from these incidents is why in this case the civil law institutions of the time were so weak that Polish tenants of properties in those areas were not able to regain possession of their tenancies by ordinary process in the civil courts.

In the 1980s, 'taking the law at its word' became an important element of Gorbachev's tactics in regaining constitutional authority for constituent assemblies in the USSR.

A more recent example-relevant to the themes of this chapter-is the conversion in the course of transition of socialist property use rights into the liberal proprietary interests, catalogued in the numerus clausus or restricted list of civil proprietary interests found in Western legal systems. ${ }^{9}$ This process-

5 See, generally, Calabresi and Melamed (1972:1089).

6 See, generally, Reich (1972) and Szawłowski (1988). See also Raff and Taitslin (2009).

7 In political science, the poles of de jure and de facto generally involve the question of the legitimacy of a particular government, such as the status accorded by Australia to the People's Republic of China between 1948 and 1972. In law, many issues with far lower profile revolve around the oppositions of de jure and de facto, such as de jure and de facto marriage.

8 Szawłowski (1988:379n.54).

9 The closed list of legal proprietary rights is found also in the common law system (Hill $v$ Tupper [1861-73] All ER Rep 696). The apparent flexibility of property concepts in the common law is due to the area of the system known as Equity. 
approached differently in various states in transition - has seen de jure rights accorded ongoing meaning but de facto possession acquired or retained under socialism, wrongly or rightly, given a lesser status. The approaches taken to this question in different states in transition lead to different balances between the interests of major stakeholders in the post-socialist settlement of property issues. In this chapter, consequently, the formal legal status of power and property arrangements is treated as a serious concern, but not without awareness of issues of party control and Realpolitik in the affairs of the Eastern Bloc.

\section{The Postwar Socialist Legal System}

When discussing the postwar Polish socialist legal system, it is important to keep in mind Poland's own heritage of left-wing parties. The Polish Socialist Party formed in 1892. Social-Democracy in the King dom of Poland and Lithuania (SDKPiL), which was ideologically close to Russian social democracy, split from the Polish Socialist Party in 1893. The Communist Party of Poland was formed in 1918 as an amalgamation of SDKPiL and the Polish Socialist Party Left, who were most likely in communication with the left wing of social democrats in Russia and Weimar Germany.

The Polish Workers' Party (Polska Partia Robotnicza) was formed in January 1942 by pro-Soviet Polish communists within Poland and was the heir to the heritage of the Communist Party of Poland, which had been purged and dissolved by pro-Stalinist influences in 1938. In view of the Soviet annexation of large parts of Poland pursuant to the Molotov-Ribbentrop Pact ${ }^{10}$ of August 1939, it is likely that pro-Soviet parties decided strategically to operate behind a facade of more moderate socialism.

Following the Soviet defeat of German forces in Poland in 1945, a provisional government of national unity was formed, which implemented accords achieved at the Yalta Conference. The 1946 referendum incorporated the western provinces into Poland and instituted land reforms and the nationalisation of industry.

In the 1946 election — widely acknowledged to have been rigged ${ }^{11}$ — the procommunist electoral block surrounding the Polish Workers' Party defeated the major Peasant Party (PSL) led by Mikołajczyk, a member of the government-inexile. This would not have been achieved in truly free elections. ${ }^{12}$ In 1947, the PSL was taken over by pro-communist elements when Mikołajczyk left for the

10 Treaty of Non-Aggression between Germany and the Union of Soviet Socialist Republics. In Russian: Договор о ненападении между Германией и Советским Союзом. In German: Nichtangriffsvertrag zwischen Deutschland und der Union der sozialistischen Sowjetrepubliken.

11 Taubman (2003:330).

12 Ibid., p. 289. 
West. At this point, nationalisation of industry affected industrial enterprises with more than 50 workers but private enterprise remained in the areas of trades, handicrafts and services. ${ }^{13}$ In December 1948, the Polish Workers' Party and the Polish Socialist Party (Polska Socjalistyczna Partia) united to form the Polish United Workers' Party (Polska Zjednoczona Partia Rabotnicza; PUWP). A political party claiming the title Communist Party of Poland did not re-emerge until 2002. In 1950 the reform of local government saw the introduction of a Soviet-style three-level system: 1) province (województwo); 2) district (powiat) or town (miasto); and 3) village commune (gmina or gromada). ${ }^{14}$

The Communist-led electoral bloc won the 1952 election under the slogan 'National Front for Peace and the Six Year Plan'.15 The 1952 Constitution, modelled on the Soviet Constitution of 1936, defined the Polish political system as a 'people's democracy' and declared Poland to be a country building socialism. The official name of the state became the Polish People's Republic (Polska Rzeczypospolita Ludowa). Article 1 of the new Constitution declared all law to be expression of the interests and will of the working people. The ultimate power of legislation and appointment was vested formally in the Sejm and while the Sejm was not in session its powers were to be exercised by a small Council of Ministers (Rada Ministrów). The post of President was abolished and replaced by that of Chairman of the Council. The Council of Ministers received wide powers to issue orders with the force of law. ${ }^{16}$ Behind a facade of liberal plurality, real power was exercised by the PWUP, the de facto Communist Party, which used the principle of 'democratic centralism', implying that the Politburo of the party really ran things in the name of the broader party membership. The overriding principle of the 'dictatorship of the proletariat' justified communist monopoly of power. Ministers, unless high-ranking members of the Politburo, were 'administrative implementers' of decisions taken by the party. A regional party secretary had more effective power than a minister. The system of party command ran from the top down within the party along functional and regional lines and from the Politburo into the administrative facade through the relevant ministry. ${ }^{17}$

Following reform of the judicial system in 1952, the courts were presided over by professional judges and lay assessors nominally elected by the People's Councils. A two-level system of Supreme Court supervision of the lower courts was put in place. The judicial system, however, remained under indirect and even direct

\footnotetext{
13 Leslie and Polonsky (1983:298).

14 Ibid., p. 309.

15 Ibid., p. 312.

16 Ibid., p. 310.

17 I am grateful to Associate Professor Stefan Markowski (above) for this account of party domination of the exercise of state power.
} 
party control, as experienced elsewhere in socialist countries. ${ }^{18}$ Ever-present party control, and state excesses ranging from corruption of decision making to extrajudicial killing, compromised even the concept of rule of law under which socialist legal systems purported to operate. The role of State Procurator was enlarged in line with the Soviet legal system. The office of the ProcuratorGeneral (Prokuratura) was first introduced in the Soviet Union in 1922 and in other socialist countries after World War II, although a similar organisation had already existed under Peter the Great, known as 'the eye of the monarch'. ${ }^{19}$ Although the State Procurator had criminal prosecution powers, including internal security matters, and was also subject to party influence, the office was also conceived as an ombudsman-type role. It emphasises the high level to which the Soviet legal model was imbued with a public law-orientated legal ideology that the State Procurator could also pursue citizen-citizen complaints. ${ }^{20}$

In the aftermath of the death of Stalin in 1953, the regime liberalised. In 1956 mass protests took place in Poznań. At the Seventh Plenum of the PUWP, Gomułkafor the purging and physical 'liquidation' of whom Stalin had pressed ${ }^{21}$ — was elected General Secretary. Although it was clear that the Soviet Union retained influence, even the pro-communist government of Poland managed to frustrate Soviet power at many points. A Soviet agricultural policy was resisted although personally advocated by Khrushchev. ${ }^{22}$ Following Poznań and the nomination of Gomułka, tensions had reached the point where both sides mobilised troops. ${ }^{23}$ With Soviet influence challenged in many parts of Eastern Europe in 1956, the Soviet Union appears to have recognised limitations to its involvement in the internal affairs of other socialist countries and perhaps reprioritised its objectives. The outcome might have been different had Khrushchev not believed the United States was behind the Polish troubles, ${ }^{24}$ especially in view of the preparedness of major powers over the preceding 200 years to shed blood and cause bloodshed on Polish soil. ${ }^{25}$

In this period a new course towards decentralisation of industry was announced and Workers' Councils were introduced. Collectivisation was removed from the agenda. The number of collective farms fell from 10500 in 1956 to 1300 (occupying nearly 212000 ha of land or a little more than 1 per cent of agricultural

18 In December 1981, when martial law was proclaimed in Poland, 40 judges were dismissed without process, apparently under the hand of the Chairman of the State Council acting alone, contrary to provisions governing the dismissal of judges (Szawłowski 1988:383n.73).

19 Zweigert and Kötz (1977:324-5).

20 Hazard et al. (1969:132-4, 535-6).

21 Taubman (2003:289).

22 Ibid., pp. 289-90.

23 Ibid., p. 293.

24 Ibid., p. 358.

25 See, generally, Clark (2007) and Zamoyski (2007). 
land) in $1964 .{ }^{26}$ Polish agriculture was the least collectivised among the socialist countries. How Poland escaped collectivisation is a topic of ongoing research, however, internally, the relative weakness of the PUWP, and, externally, weakening of will on the part of the Soviet Union are viable starting points. Nevertheless, the practical result was that in the sphere of land management, relations of private property remained 'facts of life' that had to be addressed by civil law, ensuring recognition of the need for civil law within the legal system. In relation to industrial property, enterprises with less than 50 workers were not nationalised legally but even when not taken over by local authorities anyway, they were subject to special taxation and general discriminatory treatment. ${ }^{27}$ So again, in contrast with the Soviet Union, for example, in Poland, small private ownership survived beyond mere cooperative or 'individual' forms.

\section{Socialist Civil Law in Poland}

The heritage of civil law in Poland is complex owing to the turbulence of Polish history. Central Poland received the French Civil Code in 1808. The western provinces were governed by the Prussian Civil Code of 1794 and by the German Bürgerlichen Gesetzbuch (BGB) from 1900. Southern Poland was subject to the Austrian Allgemeinen Bürgerlichen Gezetzbuch of 1811. The Eastern provinces were under Russian law, specifically the Zvod Prav (Svod Zakonov). ${ }^{28}$

Fusion of these sources was achieved in the Second Polish Republic. Enactment of a Code of Obligations in 1933 was followed by enactment of a Commercial Code in 1934, influenced by the French tradition of codification. In 1946 a number of laws, including the Law of Property and a Land Registration Law, were enacted in place of the prewar laws, followed by new General Principles of Civil Law in 1950 and, as in the Soviet legal system, a separate codification of Family Law, which resulted in the Family Law Code of $1964 .{ }^{29}$

The strength of the civil law tradition in Poland contrasted with that of prerevolutionary Russia and is barely comparable at all with what remained of civil law in post-revolutionary Russia. While socialist Poland shared the heritage and retained the features of the major European codifications, in 1918, revolutionary Russia had by decree abolished all 48 volumes of the Laws of the Russian Empire and sought to replace civil law with central-planning instruments, top-down

26 Lasok (1973:114).

27 Watkins (n.d.:1-2).

28 Lasok (1973:12).

29 Ibid., p. 4. 
regulatory methods and socialist economic forces. ${ }^{30}$ In Poland, postwar legal development continued prewar processes of rationalisation and codification, probably helped by the Polish tradition of legal pluralism.

The Polish Civil Code of 1964 (Kodeks Cywilny) introduced a distinction between 'socialist' and 'non-socialist' legal persons (§ 33). When interpreting and applying the code, it was necessary to bear in mind that the holding of property by the state was the basis of the political system of the Polish People's Republic and it remained under special protection of the law ( $\$ 129)$. The principle of unity of state ownership was expressed by $\S 128$, which stated that socialist national property was owned indivisibly by the state. This principle, reflecting state control of the means of production, facilitated a planned distribution of resources among state enterprises. It also marked cautious adoption of the Soviet approach to the conceptualisation of state property; however, inclusion in a Civil Code suggested that it was to be a civil law institution, although this did not extend to recognition of state enterprises as de jure owners of their assets. ${ }^{31}$

Following the mode of conventional European civil law, the Polish Civil Code of 1964 was divided into four separate books: 1) General Provisions; 2) Ownership and Other Rights in Property; 3) Obligations; and 4) Succession. As noted above, in departure from the traditional mould, family law was the subject of the dedicated Family Law Code of 1964. In view of this format, it could be said that the Civil Code owed much to the German Pandect tradition, though in content or spirit it leaned towards the Napoleonic Code Civile of 1804. The unique status of the Polish socialist Civil Code was, however, particularly apparent in its rendering of property law.

Polish property law maintained essentially a Roman law concept of ownership, ${ }^{32}$ however, some new property concepts were developed to reflect socialist conditions. Thus, a perpetual-use right was incorporated in the Civil Code. This right mainly concerned state-owned urban land and was conceived as a special right in rem - a new alienable right that was distinct from ownership yet reconcilable with state ownership of real property. ${ }^{33}$ Another example of the conventional civil law being adapted to state socialist infrastructure is in the area of the Law of Obligations. The delivery of produce and goods to

30 See Raff and Taitslin (2009) and Reich (1972).

31 Lasok (1973:7).

32 For an insightful account of the diffusion of Roman law concepts and approaches in Eastern Europe, through the Holy Roman Empire, Byzantine influences, the ius commune, and the influence of the German Pandectist tradition, see Sacco (1988).

33 The Polish Civil Code ( $\S$ 232-43); Rudziński (1973:70). The perpetual-use right was limited in time to 99 years. Rudziński suggests that this right was similar to, although narrower than, the late Roman law institution of emphyteusis (narrower in the sense that the perpetual-use right was limited in time) and thus close to the original emphyteusis before it merged with the jus perpetium in agro vectigali. In the Polish case, the holder of the use right was not obliged to give notice to the owner of the land (the state) of intention to alienate the right and the state had no right of pre-emption (jus promitimiseous) (Rudziński 1973:72). 
other enterprises within a socialist economy, according to production plans, was generally arranged in a transaction usually described as a 'contract' but which resembled only vaguely a contract on a Western civil law model. ${ }^{34}$ The Polish Civil Code of 1964 made contracts for the acquisition of future goods enforceable between agricultural producers and state secondary industries $(\S$ 613). Other provisions expressly accommodating state enterprises included $\S$ 535, contemplating that there would be no transfer of ownership in transactions between state organisations; $\S 540$, allowing the state to specify how prices were to be calculated; and $\S 550$, allowing contracts between state entities to provide a monopoly of supply or distribution.

Title to immovable property was to be transferred by notarial act according to $\S 155$ and $\S 158$ of the 1964 Code, in line with $\S 1583$ of the French Civil Code, and, unlike the German system, which requires in addition entry in the Land Title Register to achieve transfer of title. ${ }^{35}$

Similar to Article 131 of the Soviet Constitution of 1936, in Arts 8 and 77 of the Polish Constitution of 1950, state property was described as the unshakable foundation of the development of the state, the source of wealth and power of the Fatherland and an object of special protection. State property was defined in $\S \S$ 126-9 of the 1964 Civil Code as the highest form of socialist property. ${ }^{36}$ Poland's counterpart to the rules of socialist society provided for in Art. 130 of Stalin's Soviet Constitution of 1936 and the rules of socialist intercourse provided for in $\S 5$ of the Civil Code of the Russian Socialist Federal Soviet Republic (RSFSR) of 1964 was to be found in $\S 5$ of the Polish Civil Code of $1964 .{ }^{37}$ A duty to use objects of state property according to their assigned purpose was provided in $\S 141 .^{38}$

State-owned land could not be acquired by usucapion ( $§ 177)$. State-owned movable property that formed a component part of permanent equipment could be recovered even from a bona fide purchaser and there was no period of limitation on recovery of state-owned movables. ${ }^{39}$

\footnotetext{
34 See generally, Zweigert and Kötz (1977:337-52).

35 Rudziński (1973:74); however, also similar to $§ 187$ of the RSFSR Civil Code of 1922. The Polish system of land title registration was introduced by decree in 1946 but only mortgages and perpetual usufructs were required to be registered in the Land Title Register (Koziebrodzki 1973:127-9). New land cadastres were introduced by decree in 1955 setting out a classification of land into six classes. They served as the basis for assessment of land taxes and 'compulsory deliveries', among other things (Koziebrodzki 1973:123-4). 'Compulsory deliveries' were more analogous to an enforceable state quota for and exaction of specified agricultural goods, such as the deliveries required of Soviet Kolkhozes, than a form of agricultural land tax. Farmers might have gained an enlarged perception of their autonomy when they were characterised as a taxin-kind rather than concede their quasi-participation in a state that required its entities to deliver on quotas.

36 Rudziński (1973:75).

37 Ibid., p. 83.

38 Ibid., p. 86.

$39 \S \S 171$ and 223(2).
} 
In contrast with Soviet law, according to which unoccupied things fell under state ownership, ${ }^{40}$ the Polish Civil Code retained Roman law principles on the acquisition of res nullius by occupation ( $(181)$. The provision in $\S 182$ for ownership of migrant swarms of bees ${ }^{41}$ could well have derived from the Prussian Civil Code of $1794^{42}$ and $\S 964$ of the German BGB.

A further contrast with the Soviet property model, which provided one category of personal property as a form of private property, ${ }^{43}$ was $\S 44$ of the General Part of the Polish Civil Code, which distinguished two categories of personal property: 1) individual property of natural persons or of legal persons that was not part of the socialised economy; and 2) personal property of the natural person. Szawłowski agrees that this was a very significant distinction between Polish and Soviet socialist civil law. ${ }^{44}$

In $\S 140$ of the Polish Civil Code, ownership was defined through: 1) the right of use, according to the socioeconomic purpose of the thing; ${ }^{45}$ and 2) the right of disposition. Although the right of possession was omitted from the definition of ownership, ${ }^{46}$ the Polish Civil Code retained provisions recognising rights of possession and provided special court proceedings to regain those rights. Wilful violation of possession was forbidden by $\S 342$, and $\S 343$ allowed the possessor a right of self-help in addition to the remedy of suing against violation of possession to restore the status quo ante. ${ }^{47}$ In contrast, the Civil Code of the RSFSR of 1964 did not provide court proceedings for the protection of possession; $\S 157$ protected only rights of possession by virtue of law or contract. As Rudziński rightly observed, the difference could be explained by the preservation of private property in land in rural Poland. ${ }^{48}$

Under Title III, entitled Limited Proprietary Rights, the Polish Civil Code of $1964^{49}$ recognised the usufruct as a limited alienable proprietary right, alongside

\footnotetext{
$40 \S 143$ of the Civil Code of the RSFSR of 1964.

41 Rudziński (1973:91).

42 Allgemeines Landrecht für die Preußischen Staaten von 1794 [‘ALR'], Title 9, §§ 118-26. § 124 provides for change of rights over escaped swarms. See, generally, Hattenhauer and Bernert (1994).

43 'Personal property' in the sense of personal belongings, rather than movable property, though they were that as well.

44 Szawłowski (1988:380-1).

45 Also found in $\S 1$ of the Civil Code of the RSFSR of 1922.

46 In contrast with $\S 544$ of the French Civil Code, $\S \S 354$ and 362 of the Austrian Civil Code of 1811, and $\S$ 262 of the Svod Zakonov of 1832 ( $\$ 420$ of the 1914 revision).

47 Polish Civil Code, $\$ \S 59-60$.

48 Rudziński (1973:98-9). One point of similarity between socialist systems of civil law was the limit on residential space allotted to a cohabiting married couple and their minor children. In the Soviet Union, it was restricted to $60 \mathrm{sq} \mathrm{m}(\S 106[\mathrm{iv}]$ of the RSFSR Civil Code of 1964). In Poland, the upper limit was 110-40 sq $\mathrm{m}$ until the 1980s, when it was increased to 200-20 sq m (Szawłowski 1988:380n.60).

49 Following the French Civil Code (§§ 578-624).
} 
the servitude, the pledge, and the mortgage $(\S \S 244-51) .{ }^{50}$ Thus, the Polish civil law continued to recognise the main conventional limited proprietary rights - a point of sophistication that was not regained in Russia under socialism.

Although - or perhaps because - the Polish civil law remained sophisticated on these points, in respect of state-owned property the Polish Civil Code did not fully absorb Venediktov's concept of a 'right of operative management', which recognised that state property designated for use by a state enterprise was the object of its operative management, with accompanying rights of possession, use and disposition pertaining to it, within the limits established by law and in accordance with the plan and the purpose of the property. The right of operative management can be regarded as a de facto limited proprietary right that emerged in the Soviet system. ${ }^{51}$ Similar to the formal provisions establishing the Soviet property model, $^{52}$ the postulate of unity of state ownership required that all socialist property must belong indivisibly to the state, thus the Polish Civil Code provided that within the limits of their legal capacity state legal persons had to exercise in their own names the rights arising from state ownership with regard to the parts of the state-owned property managed by them. ${ }^{53}$ Thus, the Code appears to exclude any special proprietary rights vested in state enterprises. There was a paradox in asserting indivisible unity of socialist ownership in the hands of the state while granting legal personality to state enterprises and requiring them to transact in property between themselves. ${ }^{54}$

Similarly, the Polish civil law appears not to have recognised as proprietary in nature the use rights enjoyed over state land by a state organ within the socialist property model. Again, to do so would have acknowledged that the state organ had rights as against the state and thus contradicted the dogma of unity of state property. ${ }^{55}$ Nevertheless, as noted above, ${ }^{56}$ the Polish Civil Code of 1964 explicitly recognised the Roman law institutions of real and personal servitudes, though with novel conditions in $\S \S 287$ and 298 requiring accord with the principles of social cooperation and regard to local custom. ${ }^{57}$ In contrast, the Civil Code of the RSFSR of 1964 did not mention servitudes. Again, the legal provision for servitudes could be explained by preservation of private property in rural land. ${ }^{58}$ The same reasoning could explain retention of the mortgage,

\footnotetext{
50 Negru (1975:45) and Rudziński (1973:100-1). A right to housing construction with respect to cooperative apartment buildings was also recognised.

51 See Raff and Taitslin (2009). 'Rights of operative management' were eventually incorporated into $\S 94$ of the Civil Code of the RSFSR of 1964.

52 For example, $\S 94$ of the Civil Code of the RSFSR of 1964.

$53 \S 128(1)$. Negru (1975:24).

54 Ibid., p. 95. See also Raff and Taitslin (2009).

55 Negru (1975:102). One might draw comparison with the use rights over state land held by an agricultural cooperative $(\$ \S 271-82)$

56 See Note 49

57 Rudziński (1973:102).

58 Ibid., p. 103.
} 
although $\S 244(2)$ left the regulation of mortgages and the cooperative right to apartment buildings to provisions outside the Civil Code, just as $\S 46$ did with respect to the Land Title Register.

Private property in rural land was retained in Poland but there was a limit with respect to the size of holdings. The upper limit for peasant farms was fixed by $\S 161$ of the Civil Code at 15 ha or 20 ha under intensive cultivation. An amendment in 1971 to $\S \S 161(1)$ and 165 allowed for the limit to be raised by a permit of the relevant administrative authority. ${ }^{59}$ Beside this, limits did not apply to land title transfers by inheritance. ${ }^{60}$

With respect to comparison of Polish and Soviet property law as well, we might adopt Bernard Rudden's insight, developed in relation to a connected field, that 'Soviet law...only partially profited from...Roman insights', ${ }^{61}$ whereas judged by legal principle at least, Polish civil law remained within the EuropeanRoman tradition.

\section{Worker Participation and Industry Reforms}

There were several attempts at reform in postwar socialist Poland: in the aftermath of the October 1956 Poznan protests during the Gomułka reign, following the December 1970 Gdansk riots under Gierek's leadership, and after the Solidarity trade union strikes in the summer of 1980 under Jaruzelski. Kamiński described the trend of Polish development as 'centrally planned anarchy'. ${ }^{2}$ In light of unfulfilled promises of industrial democracy in the 1950s, demands for worker self-management resurfaced in the 1970s and again in the 1980s. Already under Gierek, significant relaxation of control over the economy had taken place. ${ }^{63}$ Even more decentralisation of decision making came to life in the 1980s.

In 1983, the Constitution was amended to include Art. 15(3), guaranteeing the continued existence of family farms. Partial legalisation in 1980 of black-market activities, which had long been part of the domestic economy, contributed to building up the private sector. ${ }^{64}$ During 1980-89, it grew from 6 per cent to 9 per cent of the economy. ${ }^{65}$

\footnotetext{
59 Ibid., p. 77.

60 Ibid., p. 78. §§ 163, 1061, 1062, 1067.

61 Rudden (1989).

62 Kamiński (1991:103).

63 Ibid. 'Late' socialism attempted to support artificially high levels of consumption and production (and thus full employment) only to accelerate the debt spiral.

64 Pchalska (1999).

65 Kamiński (1991:179). The 'second economy' grew from 5 per cent to 15 per cent (Adam 1996:174).
} 
Following the inroads of the Solidarity movement, the State Enterprise Act of 1981 decentralised ownership of productive resources. The assets of enterprises were divided into

- enterprise capital, accumulated by the enterprise through its operations

- founding capital, provided by the state, with the enterprise paying to the state a dividend proportional to the amount of state-owned assets. If there was a failure to pay the dividend, the enterprise was reorganised by the ministry or relevant local authority, which served as its founding organ. ${ }^{66}$ The 'enterprise organ' was introduced, consisting of the enterprise management and Workers' Council, which had power alongside the founding organ in the appointment and dismissal of enterprise management, to oversee enterprise operations. ${ }^{67}$

Self-managed bodies received extended decision-making powers, though the founders of them had the right to appoint the top managers in 'strategic' enterprises. ${ }^{68}$ The reforms transferred the rights of appointment from ministries to self-governing bodies. ${ }^{69}$ Enterprises received certain use rights. ${ }^{70}$ The idea behind the Kierunki reforms of the 1980s had been to establish direct industrial democracy. Enterprises were to become profit-maximising participants in a regulated market. ${ }^{71}$ Although neither the reforms of the late 1950 s nor these later attempts allowed workers' self-management to become the 'magic bullet' to save the socialist economy, it did encourage a multi-polarity of powers in Polish society, which, indirectly at least, contributed to the rise of Solidarity, and the eventual demise of socialism in Poland.

\section{Reforms Post-1989}

\section{Reform of the Civil Law}

In the 1990s and 2000s, the Polish Civil Code was repeatedly amended to remove legal concepts associated with socialism, commencing with the duty to protect social property in $\S 127(1)$ and the classification of property and privileging of state property in $\S 126$. The Land and Mortgage Register Act, the Civil Procedure Code, the Cooperative Act and the Housing Act were all introduced in 1991. The Commercial Code, rehabilitated in the 1980s, was further reformed in the 1990s.

66 Watkins (n.d.:1-2).

67 Ibid.

68 Adam (1996:173).

69 Ibid., p. 171.

70 Ibid. Adam doubts that managers received title to future benefits from the resources, or 'vested' rights.

71 Kamiński (1991:51). 
The new Constitution was enacted in 1997, providing constitutional protection to private property (Art. 64). Interestingly, the notions of socioeconomic purpose and the principle of social coexistence (Art. 140) did survive the demise of socialism. ${ }^{72}$

The Polish Civil Code of 1964, in contrast with the state of the civil law in the Soviet Union, even considering the Civil Code of the RSFSR of 1964, retained a high level of sophistication for Poland's civil law, particularly in relation to private property and specifically in the sphere of property in land. The quality of the 1964 Polish Civil Code is affirmed by the fact that the Civil Code survived the collapse of Polish socialism with relatively few changes. At a more general level, the strong pre-socialist Polish civil law tradition and the retention of civil law institutions at least de jure through the socialist era placed Poland in a position of advantage as she emerged from socialism and a position of leadership among the legal systems of Eastern Europe.

In 2004, Poland entered the European Union, and momentum appears to be building to develop a new Polish Civil Code, perhaps to better integrate provisions required by the European Union as a precondition of accession, such as paragraphs concerning consumer protection. ${ }^{73}$ It will be interesting to see whether a new Civil Code of Poland emerges before the project is overtaken by that to develop a Civil Code of Europe. ${ }^{74}$

\section{Privatisation}

Poland's privatisation program was very heterogeneous in comparison with many other states in Eastern Europe. A decree of 1982 already allowed for the sale of small businesses and service outlets to private persons. ${ }^{75}$

Following perestroika in the USSR, and disintegration of socialist regimes, an initial wave of so-called 'spontaneous privatisation' took place in the late 1980s. One dubious practice in this phase was for a state enterprise to be merged with a poorly performing private firm - preferably controlled by the managers of the state enterprise - in order to reduce the value of state assets through the merger and, thus, the overall price of the enterprise in subsequent privatisation. ${ }^{76} \mathrm{In}$ the 1990s, a phase of privatisation through 'legal liquidation' also took place. An enterprise's assets could be sold, leased or invested in a new company, of which a majority of the employees of the enterprise became proprietors. ${ }^{77}$

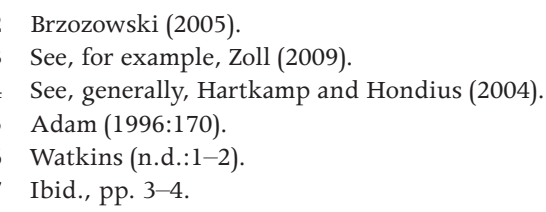


The Privatisation Act of 1990 envisioned the conversion of state enterprises into state-owned corporations, which later would be privatised. Once the enterprise was corporatised, the Workers' Council was dissolved. Employees were, however, able to elect one-third of the board of directors, with the remaining two-thirds appointed by the state. ${ }^{78}$

\section{Large-Scale Privatisation in Poland}

The privatisation legislation of 1990 was to govern the transfer of state property into private interests, providing a framework for the public offering of shares and the creation of a stock exchange in Warsaw (WSE). The legislation established the Ministry of Property Change. In November 1990, shares in the first five state enterprises were offered for sale, with the state treasury retaining from 17.5 per cent to 30 per cent of shares in three of the enterprises. Between 25 per cent and 40 per cent of the shares of any single enterprise were open to foreign investment. ${ }^{79}$ By mid-1992, however, only 14 companies were trading on the Warsaw Stock Exchange.

In 1991, a scheme was announced to privatise 400 of the largest Polish state enterprises through the establishment of National Investment Funds (NIFs). ${ }^{80}$ The creation of private investment funds was prohibited. The scheme was delayed until 1995 to permit the drafting of disclosure rules and fiduciary standards for directors. ${ }^{81}$ At least 15 NIFs were created. The NIFs were to accept vouchers distributed to the population because initially vouchers could not be invested directly in privatised stock. The NIFs were to retain a 33.33 per cent stake in each of the privatised enterprises. ${ }^{82}$ Until late 1998, the Polish government held majority voting powers in the NIFs, providing some reassurance for minority shareholders against mistreatment by controlling shareholders.

For the first post-communist government, privatisation was not a priority, due partly to pressure from the supporters of employee self-government. ${ }^{83} \mathrm{~A}$ peculiarity of the Polish experience was to rely in the early days of transition on privatisation by means of 'lease-purchase' agreements when a state enterprise was being liquidated. The assets of the enterprise were 'leased' to a new company, generally controlled by the former employees and management of the enterprise. ${ }^{84}$ The employee-owned enterprises later became targets in the phase of so-called 'secondary privatisation', when a dominant shareholder

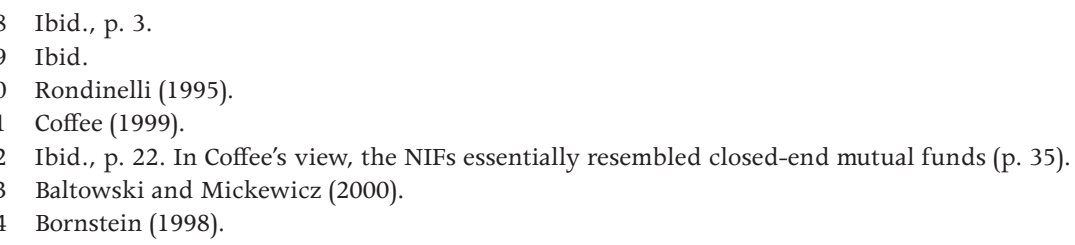


would emerge within the company or an outsider would acquire control. ${ }^{85}$ The program of 'mass privatisation' of traditional industries started later in Poland than in other Eastern European countries, such as the Czech Republic.

In relation to privatisation, Poland's experience was not extraordinary but it was certainly very sound. Poland has performed very well in setting up new businesses outside the state-owned sector. Here again, the retention of a private sector under socialism was probably an advantage, as was the reinvigoration and reform of the legal framework for the protection of private property, particularly in the corporate sector, such as establishing transparent records of title to property and other interests in it, as well as action against predatory practices, such as 'creeping control' acquisitions in which a shareholder is able to assemble a controlling shareholding without tendering for all shares. ${ }^{86}$

\section{Restitution}

In 1990, a scheme was put in place to make restitution for expropriation of assets by the Polish government between 1944 and 1962. Restitution could take the form of capital bonds, cash or return of the expropriated asset. The restitution was subject to limitations. It was not to

- obstruct the overall privatisation process

- become a burden for a large part of society

- violate existing laws and social norms. ${ }^{87}$

As experienced generally in Eastern Europe, restitution in Poland has been selective. The restitution of church property began even before Solidarity gained power. ${ }^{88} \mathrm{~A}$ more difficult question has concerned property that changed hands due to events in World War II. In Poland, as in the Czech Republic, there is resistance to establishment of restitutionary processes with respect to private property formerly held by the German ethnic minority. This objection, as well as reluctance to establish restitutionary processes with respect to formerly Ukrainian private property, could well be explained by the historical cataclysms in which the shift of relevant borders and the emigration of affected groups took place ${ }^{89}$ Similar lack of will is apparent with respect to restitution of formerly Jewish property — again, as in many other Eastern European countries.

\footnotetext{
85 Baltowski and Mickewicz (2000:434).

86 Coffee (1999:69).

87 Rondinelli (1995).

88 Appel (2005).

89 Ibid., pp. 393-4.
} 


\section{Conclusion}

Poland took leadership through democratisation of her Constitution, represented pre-eminently by the elections for the Sejm and new Senate held on 4 June 1989, and also through her rebuilding of the civil law and her privatisation initiatives. This was assisted by retention of her strong European civil law tradition, which she indeed consolidated during the socialist era.

The strength of Poland's civil law and institutions contrasts with that of the former Soviet Union, where the civil law system had been levelled in the revolutionary phase and did not regain effective strength during the socialist era, even considering the Civil Code of the RSFSR of 1964. Although earlier than the Polish Code, the Hungarian Civil Code of 1959 is grouped more closely with Soviet civil law. Poland's socialist Civil Code of 1964 provided leadership to other states within the socialist world in the development of their own socialist civil codes, such as the Czechoslovakian Civil Code of 1964 and the East German Civil Code of $1975 .{ }^{90}$ With more significance from an ideological point of view, Poland retained the concept of private ownership, even if limited in practice, but also allowed small businesses, family farms and peasant holdings to remain in private hands. The USSR had, in the early years following the revolution of October 1917, conflated civil law with bourgeois law and sought to abolish it in favour of central planning and other top-down public law systems. Within her civil law system, Poland retained the conventional limited proprietary rights, and with them a higher level of legal sophistication.

The wider research project underlying this chapter is inquiring more deeply into the causes and consequences of these variations in socialist civil law frameworks. At this point, and in celebration of Poland's leadership in her breakthrough to democracy 20 years ago, we advance our hypothesis that retention of a strong civil law, or priority in rebuilding it, is an advantage in processes of transition from socialism. Poland's success in the development of a market economy also followed from the establishment of favourable conditions for new business. Crucial steps in this included the legal protection of private property, including transparent records of ownership and other interests, high disclosure standards and restrictions on predatory practices. In Poland, these steps could well have been more important for development of her social market economy than privatisation of state-owned industry. ${ }^{91}$ Nevertheless, there is a strong case that Poland's transition from socialism was advanced by her more sophisticated civil law structures in which she had already shown strong leadership in socialist Eastern Europe.

90 Petev (1975:22-31). There were also deviations between these Codes, such as the treatment of state enterprises (see Kiralfy 1979).

91 Coffee (1999:69). 
Note: This chapter was presented as a paper at the symposium The Democratic Breakthrough - 20 Years after the June 1989 Elections in Poland, hosted by the Ambassador of the Republic of Poland and the National Europe Centre, APCD Lecture Theatre, Hedley Bull Building, The Australian National University, Canberra, 7 July 2009. I wish to express my gratitude to His Excellency the Ambassador, Andrzej Jaroszyski, and the Director of the National Europe Centre, ANU, Professor Simon Bronitt, for their kind invitation to speak at this celebration. I also wish to express my gratitude to my colleague Dr Anna Taitslin for her generous contribution to this paper and to Associate Professor Stefan Markowski, School of Business, University of New South Wales, for his insightful comments. Participants were requested to relate their personal experiences of Poland in 1989 and mine form the introductory paragraphs of this chapter.

\section{References}

Adam, J. 1996. Why Did the Socialist System Collapse in Central and Eastern European Countries?, St Martin's Press, New York.

Appel, H. 2005. 'Anti-communist justice and founding the post-communist order: lustration and restitution in Central Europe', East European Politics and Societies, vol. 19, no. 3, pp. 392-3.

Baltowski, M. and Mickewicz, T. 2000. 'Privatization in Poland: ten years after', Post-Communist Economies, vol. 12, no. 4, pp. 425-6.

Bornstein, M. 1998. Framework issues in the privatisation strategies of the Czech Republic, Hungary, and Poland, Working Paper No. 171, June, The Williamson Davidson Institute, Ann Arbor, Mich.

Brzozowski, A. 2005. 'Civil law', in S. Frankowski (ed.), Introduction to Polish Law, Kluwer Law International, The Hague.

Calabresi, G. and Melamed, A. D. 1972. 'Property rules, liability rules, and inalienability: one view of the cathedral', Harvard Law Review, vol. 85, p. 1089.

Clark, C. 2007. Iron Kingdom - The rise and downfall of Prussia 1600-1947, Penguin, London.

Coffee, J. C. 1999. Privatisation and corporate governance: the lessons from securities market failure, Working Paper 158, Center for Law and Economic Studies, Columbia Law School, New York, viewed 1 February 2006, <papers. ssrn.com/paper.taf?abstract_id=190568>

Hartkamp, A. S. and Hondius, E. H. 2004. Towards a European Civil Code, (Third edition), Kluwer Law International, The Hague.

Hattenhauer, H. and Bernert, G. (eds) 1994. Allgemeines Landrecht für die Preußischen Staaten von 1794, (Second edition), Luchterhand, Berlin. 
Hazard, J. N., Shapiro, I. and Maggs, P. B. (eds) 1969. The Soviet Legal System, Revised Oceana Publications, Dobbs Ferry, NY.

Kamiński, B. 1991. The Collapse of State Socialism - The case of Poland, Princeton University Press, NJ.

Kiralfy, A. K. K. 1979. 'The civil code of the German Democratic Republic', Review of Socialist Law, vol. 5, p. 79.

Koziebrodzki, L. 1973. 'Polish agrarian law', in D. Lasok (ed.), Polish Civil Law. Volume 1, A. W. Sijthoff, Leiden.

Lasok, D. (ed.) 1973. Polish Civil Law. Volume 1, A. W. Sijthoff, Leiden.

Leslie, F. K. and Polonsky, A. 1983. History of Poland Since 1863, Cambridge University Press, Cambridge.

Negru, Z. (trans. and ed.) 1975. The Polish Civil Code, A. W. Sijthoff, Leyden.

Pchalska, B. 1999. 'Some cultural and legal issues of the property law reform in Poland', in A. Seidmann, R. B. Seidmann and T. W. Walde (eds), Making Development Work, Kluwer Law International, The Hague.

Petev, V. 1975. Sozialistisches Zivilrecht, Walter de Gruyter, Berlin.

Raff, M. 1985. 'The ANZUS Treaty in depth', Peace Studies [Australia and New Zealand], July.

Raff, M. 1987. 'Promises of peace-high ideals and cynicism', Legal Service Bulletin, vol. 12, p. 113.

Raff, M. 1989. 'Come back King Canute! Greenhouse effect and the law', Environmental \& Planning Law Journal, vol. 6, p. 271.

Raff, M. 2003. Private Property and Environmental Responsibility: A comparative study of German real property law, Kluwer Law International, The Hague.

Raff, M. 2008. 'Environmental considerations in property law', Jurisprudencija [Journal of the Faculty of Law, Mykolo Romeiro University, Vilnius, Lithuania], vol. 6, p. 18.

Raff, M. and Taitslin, A. 2006-07.'Contradictions in privatization in Eastern Europe as reflection of contradictions in the socialist concept of ownership', Transcultural Studies, vols 2-3, pp. 279-308. 
Raff, M. and Taitslin, A. 2009. Trials of the civil law in the early Soviet Union-socialist civil law in comparative perspective, Presented at the Biennial Conference of the Australasian Association for Communist and PostCommunist Studies, University of Sydney, Sydney, 30 January 2009.

Reich, N. 1972. Sozialismus und Zivilrecht-Eine rechtstheoretischrechtshistorische Studie zur Zivilrechtstheorie und Kodifikationspraxis im sowjetischen Gesellschafts- und Rechtssystem, Athenäum Verlag, Frankfurt am Main.

Rondinelli, D. 1995. 'Privatisation and economic restructuring in Poland: an assessment of transition policies', American Journal of Economics and Sociology, vol. 3, pp. 3-4, viewed 1 February 2006, <www.findarticles. com/p/articles/mi_m0254/is_n2_v55/ai_18262050/>

Rudden, B. 1989. 'Review article: Soviet civil law', Review of Socialist Law, vol. 15 , pp. 31, 40 .

Rudziński, A. 1973. 'Comparative study of Polish property law', in D. Lasok (ed.), Polish Civil Law. Volume 1, A. W. Sijthoff, Leiden.

Sacco, R. 1988. 'The Romanist substratum in the civil law of the socialist countries', Review of Socialist Law, vol. 14, p. 65.

Szawłowski, R. 1988. 'A Polish introduction to the theory of civil law-a review article in a comparative law setting', Review of Socialist Law, vol. 14, pp. $363,379$.

Taubman, W. 2003. Khrushchev—The man, his era, Simon \& Schuster, London.

Watkins, T. n.d. Privatisation in Poland, San José State University Economics Department, viewed 1 February 2006, <www.sjsu.edu/faculty/Watkins/ privpoland.htm>

Zamoyski, A. 2007. The Rites of Peace: The fall of Napoleon and the Congress of Vienna, Harper Collins, New York.

Zoll, F. 2009. Die Novellierung des Polnischen Zivilgesetzbuches als Folge der Harmonisierung des EU-Rechts, Paper presented at General Consul of the Republic of Poland, Hamburg, 15 June 2009.

Zweigert, K. and Kötz, H. 1977. An Introduction to Comparative Law. Volume 1, North-Holland, Amsterdam. 